\title{
Cultural heritage as a means of heritage tourism development ${ }^{1}$
}

\author{
Alexandra Bitušíková
}

Prof. PhDr. Alexandra Bitušíková, PhD.

Matej Bel University in Banská Bystrica

Faculty of Arts

Department of Social Studies and Ethnology

Tajovského 40

97401 Banská Bystrica

Slovakia

e-mail: alexandra.bitusikova@umb.sk

Muzeológia a kultúrne dedičstvo, 2021, 9:1:81-95

DOI: $10.46284 / \mathrm{mkd} .2021 .9 .1 .5$

\section{Cultural heritage as a means of heritage tourism development}

A large number of studies within the social sciences have been devoted to the relationship between cultural heritage and cultural/ heritage tourism development in recent years and even decades. This area of study has been an object of interest for numerous disciplines, from economics, geography, sociology and history, to ethnology, sociocultural anthropology, museology and cultural studies. The study aims to present selected theories on cultural heritage and heritage tourism based on recent theoretical concepts, and to reflect their implementation within a particular national and regional context based on a case study of the Banská Bystrica Self-Governing Region, Slovakia.

Keywords: cultural heritage concepts, heritage tourism, Slovakia, Banská Bystrica region

\section{Introduction}

A large number of studies have been devoted to the relationship between cultural heritage and heritage tourism development in recent years and even decades. ${ }^{2}$ This research has been an object of interest for many disciplines, from economics, geography, sociology and history, to sociocultural anthropology and cultural studies. Multidisciplinarity, complexity and the evolution of the subject led to the establishment of heritage studies, a new specific research field mainly "exploring the impact of heritage on the present, and the development of new holistic

\footnotetext{
${ }^{1}$ The study has been based on research funded by the VEGA grant No. 1/0232/19, "Kultúrne dedičstvo ako súčast' sociokultúrneho potenciálu rozvoja turizmu v lokálnych spoločenstvách."

${ }^{2}$ TIMOTHY, Dallen J., BOYD, Stephen W. Heritage Tourism. Harlow, UK: Pearson Education Limited, 2003; TIMOTHY, Dallen J., BOYD, Stephen W. Heritage Tourism in the 21st Century: Valued Traditions and New Perspectives. In: Journal of Heritage Tourism, Vol. 1, No. 1, 2006, pp. 1-16; TIMOTHY, Dallen J. Cultural Heritage and Tourism. An Introduction. Bristol - Buffalo - Toronto: Channel View Publications, 2011; NILSSON, Per Åke. Impact of Cultural Heritage on Tourists. The Heritization Process. In: Athens Journal of Tourism, Vol. 5, No. 1, 2018, pp. 35-54; ROSENFELD, Raymond A. Cultural and Heritage Tourism. In: Municipal Economic Toolkit Project. Michigan, 2008; SALAZAR, Noel B. From Local to Global (and Back): Towards Glocal Ethnographies of Cultural Tourism. In: GREG Richards, MUNSTERS, Wil, eds.: Cultural Tourism Research Methods. CAB International, 2010, pp. 188-198; SALAZAR, Noel B. The Glocalisation of Heritage through Tourism. Balancing, standardisation and differentiation. In: LABADI, Sophia and LONG, Colin, eds.: Heritage and Globalisation. London and New York: Routledge, 2010, pp. 131-146; BUI, Huong T., LEE, Timothy J. Commodification and Politicization of heritage: Implications for Heritage Tourism and the Imperial Citadel of Thang Long, Hanoi (Vietnam). In: ASEAS_Austrian Journal of South-East Asian Studies, Vol. 8, No. 2, 2015, pp. 187-202, and others.
} 
approaches to address the complexities and challenges related to heritage". ${ }^{3}$ Cultural or heritage tourism as one of research interests of heritage scholars has been seen in two rather controversial perspectives in the era of globalisation: it is considered either more positively as a resource of revival, empowerment and development of local or regional communities, or negatively as a metaphor for destruction, erosion or commodification. ${ }^{4}$ Cultural heritage and its different meanings, definitions and understandings play a significant role in this development.

This paper gives an overview of selected theories on cultural heritage and heritage tourism, based on recent theoretical concepts from critical heritage studies. It also tries to reflect on the implementation of new approaches to heritage tourism within a particular national and regional context (Slovakia, The Banská Bystrica Self-Governing Region), on the basis of initial ethnographic research. The case demonstrates new ways of marketing and supporting the cultural heritage of the region in the twenty-first century. It is based on an analysis of existing documents, reports, websites and social media, as well as participant observation and interviews with representatives of the Development Agency Dobrý kraj and its district organisations. ${ }^{5}$

\section{Concept of cultural heritage}

The concept of cultural heritage has been theorised, defined, redefined, negotiated and renegotiated by a large number of theorists and practitioners from different disciplines as well as from the newly developed heritage studies or critical heritage studies. From the analysis of numerous scientific papers it seems that there are as many definitions of the heritage concept as there are heritage researchers. This argument has been supported by the often-quoted claims of David Lowenthal in his famous book, Heritage as Crusade, that "all at once heritage is everywhere" or "heritage today all but defies definition". ${ }^{7}$ Indeed, we live in the era of heritage revival or heritage revolution-heritage really is everywhere and it is a crucial part of local, regional or national development and tourism strategies or global tourism visions.

The heritage concept has been constructed, recontructed and updated in a number of new critical perspectives. In the traditional "Western" understanding, heritage was viewed more in a physical, material form, which meant that heritage could "be mapped, studied, managed, preserved and/or conserved," and its protection might be "the subject of national legislation and international agreements, conventions and charters". "The critical heritage literature does not look at heritage as a physical "thing" any more, but as a social and cultural construction, as a dynamic and elastic concept and process, as a continuing dialogue with the past, which "engages with acts of remembering that work to create ways to understand and engage with the present". ${ }^{9}$ Gregory Ashworth, one of the leading heritage scholars, also supports the idea

\footnotetext{
${ }^{3}$ LOULANSKI, Tolina. Revising the Concept for Cultural Heritage: The Argument for a Functional Approach. In: International Journal of Cultural Property. Vol. 13, No. 2, 2006, p. 208.

${ }^{4}$ WINTER, Tim. Heritage Tourism: The Dawn of a New Era? In: LABADI, Sophia, LONG, Colin, eds.: Global Tourism: Cultural Heritage and Economic Encounters. Lanham, New York, Toronto, Plymouth, UK: Alta Mira Press, 2010, p. 117.

${ }^{5}$ Ethnographics methods were used in a limited way due to the interruption of fieldwork during the COVID-19 pandemic. Out of six interviews with the representatives of the Good Region agency and its Regional Tourism Organisation, four had to be conducted online.

${ }^{6}$ LOWENTHAL, David. The Heritage Crusade and the Spoils of History. Cambridge: Camridge University Press, 1998, p. xiii.

${ }^{7}$ LOWENTHAL, The Heritage..., p. 94.

${ }^{8}$ SMITH, Laurajane. Uses of Heritage. London - New York: Routledge, 2006, p. 3.

${ }^{9}$ SMITH, Uses of Heritage..., p. 2.
} 
of understanding heritage as a process, and not as a form. He connects heritage with change, and refuses the idea that heritage-whether it is in a tangible or intangible cultural form-is primarily about preservation or conservation. ${ }^{10}$ Heritage is currently identified as "that part of the past that we select in the present for contemporary purposes, be they economic, cultural, political or social". ${ }^{11}$

Jacynthe Bessiére also looks at heritage as a process bridging the past, the present and the future. She stresses that heritage (whether it is an object, a monument, an inherited skill or a symbolic representation) must be seen as an identity marker and a distinguishing feature of a social group. She considers heritage as "a reservoir of meanings necessary to understand the world"-an evolving social production, which is dynamic, constantly under review and ever-changing. ${ }^{12}$ She offers a hypothesis that "the dynamics of building up heritage consist of actualising, adapting, and re-interpreting elements from the past of a given group (its knowledge, skills and values), in other words combining conservation and innovation, stability and dynamism, reproduction and creation, and consequently giving a new social meaning which generates identity and unity. “13

As many heritage scholars stress, heritage is a value-loaded concept. In his study on values and meanings of heritage, Noel Salazar pointed out that sociocultural values were attached to heritage "because it holds meaning for people or social groups due to its age, beauty, artistry or association with a significant person or event" and these values are produced though complex processes of learning, transmission and awareness building. On the other hand, heritage also has an increasingly significant economic value, mainly in the global tourism market. ${ }^{14}$ The growing trend to "sell" heritage for cultural or heritage tourists has been connected with numerous practices that sometimes can lead even to the destruction of local heritage. According to Tolina Loulanski, the controversy in defining heritage might originate in this duality of being both a cultural and economic subject, possessing both cultural and economic values and having both cultural and economic functions. She continues that heritage should bridge this gap between culture and economy by bringing both approaches together and by making theorists and practitioners from both fields talk and collaborate. ${ }^{15}$

The nature of heritage relates to present circumstances. ${ }^{16}$ As heritage is produced in the present, "our relationship with the past is understood in relation to our present temporal and spatial experience". ${ }^{17}$ Smith argues that "heritage is used to construct, reconstruct and negotiate a range of identities and social and cultural values and meanings. ${ }^{18}$ Indeed, heritage, its

\footnotetext{
${ }^{10}$ ASHWORTH, Gregory J. Heritage in Fragments: a Fragmented Instrument for Fragmented Policies. In: MURZYN, Monika, A., PURCHLA, Jacek, eds.: Cultural Heritage in the 21st Century. Opportunities and Challenges. Krakow: International Cultural Centre, 2007, p. 32.

${ }^{11}$ GRAHAM, Brian, ASHWORTH, Gregory J., TUNBRIDGE, John E. A Geography of Heritage. Power, Culture and Economy. London: Routledge, 2000, p. 2.

${ }^{12}$ BESSIÈRE, Jacinthe. Local Development and Heritage: Traditional Food and Cuisine as Tourist Attractions in Rural Areas. In: Sociologia Ruralis, Vol. 38, No. 1, 1998, pp. 26-27.

${ }^{13}$ BESSIÉRE, Local Development..., p. 27.

${ }^{14}$ SALAZAR, Noel B. Shifting Values and Meanings of Heritage. From Cultural Appropriation to Tourism Interpretation and Back. In: LYON, Sarah, WELLS, E. Christian, eds.: Global Tourism: Cultural Heritage and Economic Encounters. Lanham, New York, Toronto, Plymouth, UK: Alta Mira Press, 2012, p. 24.

${ }^{15}$ LOULANSKI, Revising the Concept..., p. 209.

${ }^{16}$ HARDY, Dennis. 1988. Historical Geography and Heritage Studies. Areas, Vol. 20, No. 4, 1988, pp. 333-338.

${ }^{17}$ HARVEY, David C. Heritage Pasts and Heritage Presents: temporality, meaning and the scope of heritage studies. In: International Journal of Heritage Studies, Vol. 7, No. 4, 2010, p. 325.

${ }^{18}$ SMITH, Uses of Heritage..., p. 3.
} 
meanings and values often represent and support local/ regional identities and lead to building a sense of solidarity, common pride and community, but at the same time-due to heritage value-based characteristics - they can play a negative role in strengthening nationalism, extermism or hatred towards "any others" who do not share "our values or our heritage". That is why it is so important to look at heritage from a critical perspective.

The heritage value is not fixed, but is always a product of interaction and interpretation, ${ }^{19}$ and often a result of power struggles among various actors. On the one hand there are external experts that ascribe certain values, meanings and functions to the heritage, based on some formal criteria; on the other hand there are local actors who can see the value or meaning of their heritage differently. This can lead to either multiple heritage narratives or to so called heritage dissonance, a mismatch between official narratives and the heritage perceptions of local residents. ${ }^{20}$ The heritage narratives have been increasingly influenced by the economic value of heritage - a result of the process of commodification of cultural heritage. UNESCO's World Heritage List, which has become an accreditation scheme for heritage sites, either serves the purposes of tourism (as a major source of revenue) or nation building. This trend illustrates how transnational processes are subject to national and local economic considerations and political agendas. ${ }^{21}$

The national, regional and local development and tourism strategies (based primarily on political and economic agendas) have been increasingly built on the heritage agenda: how to use and sell heritage to domestic and international tourists, how to strengthen the positive image of the country and how to increase revenues. Heritage-in its diverse meanings within diverse actors and stakeholders- has thus become an object of dissonant narratives when it is interpreted in different ways by various actors, or it is interpreted only in one way that serves the "official" (often national or ideological) narrative based on selected history and heritage or on manipulating history and heritage. As Graham et al. stated, "the nation-state required national heritage for a variety of reasons. It supported the consolidation of ... national identification, while absorbing or neutralising potentially competing heritages of social-cultural groups or regions". 22

\section{Heritage tourism}

Cultural heritage is currently without any doubt one of the most important resources of global tourism. At the same time, tourism can be a tool used by local communities to learn and respect their own heritage. As a result, cultural/ heritage tourism has been among those tourism sectors growing most rapidly in recent decades, being the most notable and widespread. ${ }^{23}$ Heritage and tourism scholars use the terms "cultural tourism" and "heritage tourism" sometimes as separate, but often as very related and overlapping phenomena. According to Timothy, cultural tourism is more often used in relation to participation in modern living cultures, contemporary arts and music, primarily in urban areas, while heritage tourism is connected more

\footnotetext{
${ }^{19}$ SALAZAR, Shifting Values..., p. 37.

${ }^{20}$ SALAZAR, Shifting Values..., p. 37; TUNBRIDGE, John E., ASHWORD, Gregory J. Dissonant Heritage: The Management of the Past as a Resource in Conflict. Chichester: J. Wiley, 1996.

${ }^{21}$ SALAZAR, Noel B. Imagineering cultural heritage for local-to-global audiences. In: HALBERTSMA, Marlite, van STIPRIAAN, Alex and van ULZEN, Patricia, eds.: The Heritage Theatre: Globalisation and Cultural Heritage. Newcastle upon Tyne: Cambridge Scholars Publishing, 2011, pp. 49-72; SALAZAR, Shifting Values..., 2012.

${ }^{22}$ GRAHAM, Brian, ASHWORTH, Gregory J., TUNBRIDGE, John E., A Geography of Heritage..., p. 12.

${ }^{23}$ TIMOTHY, Dallen J., BOYD, Stephen W. Heritage Tourism in the 21 st Century..., p. 1.
} 
to rural and place-bound areas and living cultures, older relics and performances. However, despite some differences, cultural tourism and heritage tourism seem to share more similarities than differences. Cultural and heritage tourists' experience is built on enjoying living and built culture in both rural and urban contexts and on their own personal experiences. ${ }^{24}$ Timothy and Boyd ${ }^{25}$ and Timothy ${ }^{26}$ therefore suggest that both terms might be used interchangeably. Following their suggestions, in this paper I mainly use the term "heritage tourism" as it seems to be more connected to rural cultures and living heritage which I will refer to later in this study.

Heritage tourism is one of the oldest forms of travel. The ancient Egyptians and Romans, and later the (mainly European) nobility of medieval times used to travel to historic places of cultural importance. ${ }^{27}$ The oldest form of tourism was pilgrimage. Early pilgrims from the period of the ancient days of the Greek and Roman empires searched for religious and spiritual experiences. ${ }^{28}$ In the next period, from the 1600 s until the mid-1800s, the Grand Tour was developed as a significant part of the history of European heritage tourism (covering Italy, France, Switzerland, Belgium, Germany, Austria and the Netherlands in particular). Young men of certain higher social strata who were expected to become part of the cultured nobility were encouraged to travel across Europe with their tutors for months or years, visit all significant arts and architecture places (Paris, Rome, Venice, Florence and other historic cities) and learn foreign languages. ${ }^{29}$ When looking back at the history of European travels we can see a long-term continuity in which a heritage tourist of today often follows similar routes and visits similar European cities, though at a faster pace. ${ }^{30}$ We could even say the Grand Tour idea contributed to building cultural capital (in Pierre Bourdieu's meaning) important for the development of a democratic and united Europe today.

In recent decades, tourism has become a global phenomenon and shows steady increases in the number of tourists every year. Heritage tourism as a specific sector of global tourism includes visits to historic sites in urban and rural areas, monuments and dwellings, museums, rural and agricultural landscapes, locations where important events happened or places of interesting living cultures. ${ }^{31}$ Heritage tourism has become one of the most studied phenomena within both heritage studies and tourism studies, and there are at least three important reasons for this (to mention just a few).

First, heritage tourism serves important political purposes. Actually, it is more political than most other tourism sectors. ${ }^{32}$ According to Salazar, on the domestic level, it contributes to stimulating pride in the "(imagined) national history" or to highlighting "the virtues of particular ideologies"; and on the supranational level, heritage sites are marketed and sold as "iconic markers of a local area, country, region or even continent". ${ }^{33}$ Timothy and Boyd similarly stress that heritage tourism is used "to build patriotism at the domestic level and spread propaganda

\footnotetext{
${ }^{24}$ TIMOTHY, Dallen, J. Cultural Heritage and Tourism..., pp. 4-5.

${ }^{25}$ TIMOTHY, Dallen J., BOYD, Stephen W. Heritage Tourism in the 21 st Century..., p. 1.

${ }^{26}$ TIMOTHY, Dallen J. Cultural Heritage and Tourism..., p. 6.

${ }^{27}$ TOWNER, John (1996). An Historical Geography of Recreation and Tourism in the Western World: 1540-1940. Chichester: Wiley, 1996; TIMOTHY, Dallen J., BOYD, Stephen W. Heritage Tourism in the 21st Century..., pp. 1-2.

${ }^{28}$ TIMOTHY, Dallen, J. Cultural Heritage And Tourism..., p. 2.

${ }^{29}$ TIMOTHY, Dallen, J. Cultural Heritage And Tourism..., p. 2.

${ }^{30}$ TIMOTHY, Dallen J., BOYD, Stephen W. Heritage Tourism, pp. 12-13.

${ }^{31}$ TIMOTHY, Dallen J., BOYD, Stephen W. Heritage Tourism in the 21 st Century..., p. 2.

${ }^{32}$ TIMOTHY, Dallen, J. Cultural Heritage and Tourism..., p. 127.

${ }^{33}$ SALAZAR, Noel B. The Glocalisation of Heritage..., p. 130.
} 
to international visitors". ${ }^{34}$ Per Åke Nilsson goes even further, using the term heritagisation, which he describes as a social process, where cultural heritage is used in order to promote certain political, often nationalistic ideas. He mentions the recent kidnapping of cultural heritage by right wing movements with the aim to strengthen their political interests. ${ }^{35}$

Second, heritage tourism as a target for domestic and foreign tourists is considered a significant source of increasing economic revenue for states, regions and localities. All countries have been trying to attract tourists on the basis of selling and interpreting their cultural heritage, and this approach has become then the key of all visions in local, regional or even national development and toursim strategies. The economic aspect (the strategy to attract as many tourists as possible) has often been a top argument in persuading these new strategies. Indeed, toursim has become a significant source of economic revenue at all levels; however, it has also had negative consequences and negative impacts on local social and cultural developments and generally on the sustainable development of any tourism destination. The term overtourism has been increasingly used in scholarly literature to describe negative impacts of mass tourism (often heritage-based) in many world regions. As Dodds and Butler stress, "overtourism is a new term for an old problem, namely, excessive numbers of tourists at a specific destination that can result in negative impacts of all types on the community involved". ${ }^{36}$ These negative impacts include worsening of the well-being and life-style of local residents, as well as increasing costs for water, energy, waste or housing that are often eight to ten times higher from tourism than those from local consumption. ${ }^{37}$

Third, heritage tourism is often seen as an agent of socio-cultural change. ${ }^{38}$ It can stimulate local and regional development, contribute to community empowerment, create business opportunities and is a source of capacity building for local people. However, this goes hand in hand with the commodification and over-commercialisation of heritage, and concerns related to these things. Heritage tourists tend to seek "real", authentic experiences and places, but with commodification of heritage, authenticity is increasingly becoming only a marketing tool and turns into what MacCannell called "staged authenticity" in which locations and local conditions are "being staged for tourist consumption". ${ }^{39}$ Authenticity has been a common and relevant object of research in many heritage disciplines. ${ }^{40}$ It has been studied in relation to handicrafts and "tourist" souvenirs; ethnic or folklore festivals; festivities organised in outdoor heritage

\footnotetext{
${ }^{34}$ TIMOTHY, Dallen J., BOYD, Stephen W. Heritage Tourism in the 21 st Century..., p. 3.

${ }^{35}$ NILSSON, Per Åke. Impact of Cultural Heritage on Tourists..., pp. 36-37.

${ }^{36}$ DODDS, Rachel, BUTLER, Richard. The Phenomena of Overtourism: a Review. In: International Journal of Tourism Cities, Vol. 5, Issue 4, 2019, p. 519.

${ }^{37}$ GÖSSLING, Stefan, PEETERS, Paul. Assessing tourism's global environmental impact 1900-2050. In: Journal of Sustainable Tourism, Vol. 23, No. 5, 2015, pp. 639-59; EPLER WOOD, Megan, MILSTEIN, Mark, AHAMED-BROADHURST, Kathleen. Destinations at Risk: The Invisible Burden of Tourism. Washington, DC: The Travel Foundation, 2019; DODDS, Rachel, BUTLER, Richard. The Phenomena of Overtourism..., pp. 519-528.

${ }^{38}$ SALAZAR, Noel, B..., The Glocalisatioin of Heritage, p. 130.

${ }^{39}$ MacCANNELL, Dean. Staged Authenticity: Arrangements of Social Space in Tourist Settings. In: American Journal of Sociology, Vol. 79, No. 3, 1973, pp. 589-603.

${ }^{40}$ APOSTOLAKIS, Alexandros. The Convergence Process in Heritage Tourism. In: Annals of Tourism Research, Vol. 40, No. 4, 2003, pp. 795-812. TIMOTHY, Dallen J., BOYD, Stephen W. Heritage Tourism. Harlow, UK: Pearson Education Limited, 2003; LABADI, Sophia. World Heritage, authenticity and post-authenticity. International and national perspectives. In: LABADI, Sophia, LONG, Colin, eds.: Heritage and Globalisation. London and New York: Routledge, 2010, pp. 66-84; TIMOTHY, Dallen, J. Cultural Heritage and Tourism..., 2011; SILVERMAN, Helaine. Heritage and Authenticity. In: WATERTON, Emma, WATSON, Steve, eds.: The Palgrave Handbook of Contemporary Heritage Research. London: Palgrave Macmillan, 2015.
} 
museums or any local performances aimed at attracting tourists and pretending to present an authentic experience. Research on authenticity remains relevant as studying and learning about the role of authenticity in visitors' experiences can have practical implications for tourism management. $^{41}$

Tourism itself has been defined and diversified according to various categories (e.g. beach/ resort tourism, ecotourism, religious tourism, sport tourism, shopping tourism, sex tourism, adventure tourism, cultural or heritage tourism). Heritage tourism has been further categorised and as research about it develops, new categories have been identified. In addition to visits to historic cities, castles, cathedrals, museums, archeological sites and monuments of all kinds (built heritage), we can see the rise in popularity of newer specific heritage categories, such as industrial heritage, religious sites and pilgrimage, personal heritage tourism (genealogy, roots and diasporas), indigenous cultures, heritage routes and trails and dark tourism/ thanatourism-visits to places of death, atrocity or other forms of human suffering. ${ }^{42}$

Community tourism or community-based tourism is another category that can be closely related to heritage tourism. It refers to tourism that "involves community participation and aims to generate benefits for local communities... by allowing tourists to visit these communities and learn about their culture and the local environment". ${ }^{43}$ Although community tourism is usually mentioned in relation to developing countries, the concept has been increasingly used in any other countries where local communities initiate and participate in various activities for tourists.

\section{Heritage tourism in Slovakia}

Slovakia as a rather new and unknown country that only gained its independence after the split of Czechoslovakia in 1993, and has been trying to invent and re-invent its image in order to sell it to the global tourism market since its establishment. With a population of 5.4 million, the country is ethnically rather homogeneous (81\% Slovaks, almost $9 \%$ Hungarians, $2 \%$ Roma, with the remainder being made up of Czechs, Ukrainians, Ruthenians/Rusyns, and others). However, Slovakia's very diverse geography (from lowlands to high mountains, being the territory between the Pannonia-Tisza zone and the Carpathian geographic zone) and religious divisions (being on the European line between Catholicism and the Orthodox and Greek Orthodox) make the small country an increasingly interesting tourism target. And the particular key to tourism interest has been its heritage, both natural and cultural.

Slovakia has so far not been very successful in its efforts to attract heritage tourists to all of its regions. The Bratislava region has been the most successful-mainly due to the fact that it is geographically close to Vienna and Budapest, and "travel packages" introduced by various tourism agencies usually offer a quick visit to all three Central European capitals. Geographically further regions of Slovakia have been trying to attract visitors to areas outside the Bratislava region, using various strategies, often based on heritage narratives.

The key strategic document Strategy for Tourism Development 2020 identifies three main objectives, with one of them directly linked to marginalised regions:

- to support destinations with a sufficient natural and cultural-historical potential in stagnant

\footnotetext{
${ }^{41}$ TIMOTHY, Dallen J., BOYD, Stephen W. Heritage Tourism in the 21 st Century..., p. 7.

${ }^{42}$ TIMOTHY, Dallen J., BOYD, Stephen W. Heritage Tourism in the 21 st Century..., pp. 7-11.

${ }^{43}$ LUCCHETTI, Veronica Garcia, FONT, Xavier. Community Based Tourism: Critical Success Factors. ICRT Occasional Paper, No. OP27, 2013, Australia - Dubai: The International Centre for Responsible Tourism, p. 2.
} 
(marginalised) regions with high unemployment and to create new job opportunities. ${ }^{44}$

The following case study focuses on a region that belongs to the category of stagnant regions.

\section{Case study: The Banská Bystrica Dobrý kraj (The Good Region Banská Bystrica)}

The following case demonstrates new visions and objectives of the regional strategy to develop heritage tourism in the Self-Governing Region of Banska Bystrica (BBSK), Central Slovakia. The region is the largest of eight self-governing regions in Slovakia and has a population of 660 thousand people. It is a very heterogeneous region in terms of geography as well as economic and social structure. Generally it consists of the better-developed mountainous north, and the more stagnant flat and agrarian south, bordering with Hungary. The long-term unemployment rate in the region is higher than the country's average (4.98\%) and was at $6.67 \%$ in January 2020, with large district differences within the region ranging from 3\% to $15 \%$ (the main reason for the high unemployment rate in several southern districts is the high Roma minority population).

Several localities of the region were historically connected with mining, glass and metal industries of global importance and possess outstanding cultural and technical heritage. In addition, several parts of the region are suitable for the development of rural, nature-based tourism or agrotourism, offering the tranquillity of the countryside. Despite being one of the most attractive regions in Slovakia in terms of cultural and natural heritage, its potential has been vastly underrated and underused, mainly because of its rather weak infrastructure (without a motorway or a nearby airport) and non-effective marketing. It is also important to stress that the region was paralysed during the governance of the neo-Nazi governor Marian Kotleba (2013-2017), which means that for a four-year period any European funding for the support of infrastuctural investments in the Banská Bystrica region was stopped. In addition, development of tourism was not a priority for the BBSK in this period.

After the 2017 regional elections when Marian Kotleba and his right-wing neo-Nazi party representatives lost their positions in regional political structures ${ }^{45}$ (though getting positions in the national parliament), the new regional governor and his team started to develop new strategies and policies in all sectors, including tourism. One of the first steps was the establishment of the Development Agency of the Self-Governing Region Banská Bystrica (BBSK) called Dobrý kraj (The Good Region). ${ }^{46}$ In addition to strategic planning, education, health care and social economy, tourism has been identified as one of the priorities. The development of tourism in the region has been presented under a new communication and marketing destination brand, Za horami, za dolami (Beyond mountains, beyond valleys) — a well-known initial phrase from Slovak fairy tales meaning "somewhere far, far away". This communication strategy builds on an old storytelling and fairy-tales tradition of Pavol Dobšinský, one of the most important and well-known collectors of Slovak folk tales in the nineteenth century. Dobšinský was born in the region and was the author of a series of eight volumes of the most complete collection of Slovak fairy-tales called "Prostonárodnie slovenské povesti" (Slovak folk tales, 1880-1883), an extraordinary collection comparable to the Grimms’ Fairy Tales collection. Dobšinskýs mes-

\footnotetext{
44 Stratégia rozvoja cestovného ruchu do roku 2020. Adopted by the Government of the Slovak Republic No. $379 / 2013$ from 10 July 2013.

${ }^{45}$ Marian Kotleba lost his position of the regional governor mainly because of a broad civic campaign led by the local grassroots movement Not in Our Town, www.niot.sk.

${ }^{46}$ https://dobrykraj.sk/; accessed on 12 May 2020.
} 
sage to slow down, return to one's roots and experience adventure (words expressed by him in the nineteenth century) has been the key message in the regional tourism strategy regarding reasons to visit the Banská Bystrica region.

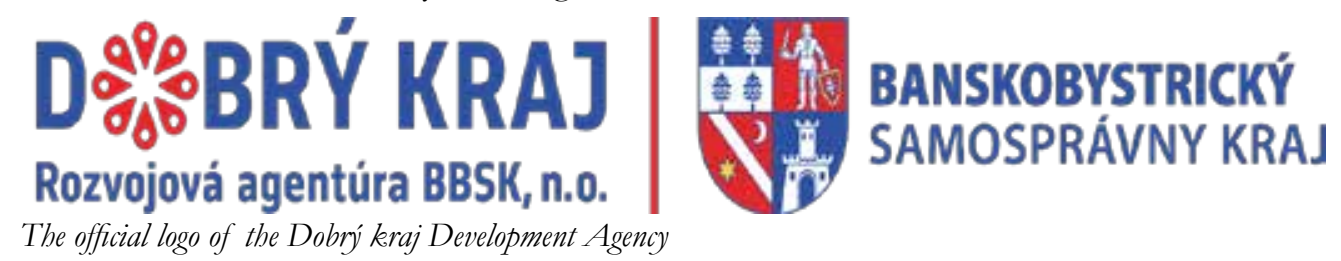

The initial idea of the new branding was followed by important structural changes. In 2018, seven district tourism organisations ${ }^{47}$ co-established a "Regional Organisation of the Banska Bystrica Tourism” (Krajská organizácia cestovnébo ruchu Banskobystrický kraj Turizmus) as part of the Development Agency with the aim to support common conditions for the development of tourism in the Banská Bystrica region. According to the head of the organisation,

the key to cooperation among these seven district organisations is networking through 27 thematic working groups. Their objective is to define and prepare best tourism products based on local identity and to connect or involve local people in the organistion of various activities and services (including accommodation and gastronomy services. This networking and participatory approach aims at creating job opportunities for local people and contributing to regional development.

The new regional tourism strategy has been built partly on rural tourism and agrotourism, following one of the objectives of the national strategy on tourism. ${ }^{48}$ As one of the founders of the regional tourism organisation noted, "part of the strategy has been inspired by rather specific tourism visions that use the (supposed) non-attractiveness or low knowledge of the region based on slogans such as 'there is nothing specific here' as the key attraction." In times of "overtourism", ${ }^{49}$ and excessive tourism marketing (not only officially, but mainly through informal social media), this strategy seems to work in various parts of the world, mainly because many travellers start to look for places without tourists. The Banská Bystrica region can offer many such attractions.

The heritage tourism brand of the Banská Bystrica Good Region, Za horami za dolami (Beyond mountains, beyond valleys) has so far included eight tourism destinations (2020). ${ }^{50}$ It follows a communication strategy built on the storytelling of a heritage bearer-a craftsman, a traditional farmer, a food producer or a folk costume maker, based on the authenticity of their personal story. Since 2020, the website has offered the personal stories of twelve "ambassadors" from concrete tourism destinations of the region, who are representatives of diverse tangible and intangible traditions: a lace-maker from Špania Dolina, a pottery-maker and back-piper from the Hron Region, a blacksmith from the Gemer district, and activists from the Čierny Hron railway and the Banská Štiavnica Calvary, as well as a number of local producers of wine,

\footnotetext{
${ }^{47}$ District organisations-Oblastné organizácie cestovného ruchu (OOCR): OOCR Stredné Slovensko, OOCR Región Banská Štiavnica, OOCR Dudince, OOCR Horehronie, OOCR Gron, OOCR Turistický Novohrad a Podpol'anie and OOCR Gemer. Each of these organisations has two district coordinators.

${ }^{48}$ Marketingová stratégia SACR na roky 2014-2020, pp. 23-24.

49 PECHLANER, Harald, INNERHOFEER, Elisa, ERSCHBAMER, Greta. Overtourism. Tourism Management and Solutions. London: Routledge, 2019.

${ }^{50}$ https://www.zahoramizadolami.sk/wp-content/uploads/2019/01/Za-horami-za-dolami_brozura_A5.pdf; _ accessed on 21 January 2021.
} 


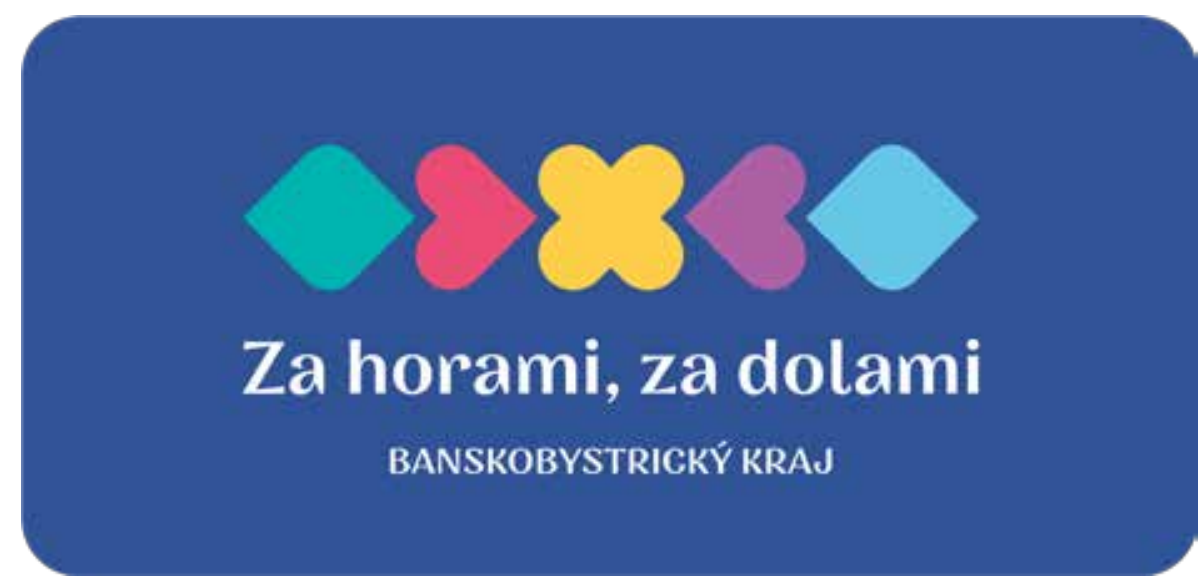

The official logo of the Beyond Mountains, beyond valleys brand

honey or cheese. ${ }^{51}$ This method of heritage tourism marketing focuses on a more intimate and emotional contact between the heritage bearer and the potential customer.

The governor of the Banská Bystrica region Ján Lunter stressed:

„Changing the perception of our region is extremely important for us. Beautiful nature is often undiscovered, traditions and customs unknown. We try to take inspiration from the countries that know how to use a country's potential and at the same time protect and enhance it. “" ${ }^{\circ}$

The Development Agency Dobrý kraj and its regional tourism organisation collaborate intensively with international partners. Since 2019 this has also taken place through the project "Catching-up", initiated and funded by the European Commission and the World Bank.

The heritage tourism brand Beyond mountains, beyond valleys is focused on so-called experience tourism (or experiential tourism) which has become very popular in recent years. Tourists, travellers or visitors increasingly prefer to spend their money on special experiences rather than on commodities. This kind of tourism is more about personal life-enriching experiences, learning about new cultural and natural landsacpes, meeting local people, gaining new skills and even about self-discovery. As the head of the Regional Agency expressed:

Experience is a key word for us. We want to provide special, emotional experiences to visitors. However, our main target is not profit, but regional development. Most of our tourism products aim at small groups up to five people, for example cultural-natural and educational walks in marginalised corners of the region (such as the Tour of the folklore hero - rebel Burda in the Horehron region or the Tour of wooden barns in the Gron district).

Beyond mountains, beyond valleys tourism products are offered under various categories: Learn about your region; Discover stories and narratives; Regional products; Experience someting extraordinary in the region; and Buy an experience. Under these categories a visitor can find numerous opportunities to discover the region. S/he can choose from The Horehron Train Route (the most successful of all the attractions); The Mining Train Route; The Hron River Mysterious Castle Route; The Glass Route; The Iron Route; Exploring Wooden Barns; Discovering Celtic Settlements; or personal visits to bearers of tradition-a honey-maker, a cheese-maker

\footnotetext{
${ }^{51}$ https://www.zahoramizadolami.sk/\#objav-pribehy; accessed on 16 May 2020.

52 https://mybystrica.sme.sk/c/22037184/za-horami-za-dolami-tak-sa-vola-nova-turisticka-znacka.html; accessed on 15 June 2020.
} 
or a wine producer. ${ }^{53}$ As visitors want to experience someting special or to learn new skills, they can spend a day working with a farmer in the Podpol'anie region, learn how to make original regional embroidery or experience putting on and wearing traditional folk costume. In 2020, fifty-seven unique "experiences" were offered to visitors ${ }^{54}$ and the plan is to add new ones, such as The Castle Route in the south of the region on the Hungarian border (Fil'akovo, Šomoška, Divín, Modrý Kameň), with the aim of attracting more tourists from Hungary.

The strategy behind the brand builds on participatory models in tourism development that are broadly also accepted as a criterion for sustainable tourism. Collaborative participatory models tend to involve various stakeholders in tourism development and thus offer visitors opportunities to meet local people in real situations. ${ }^{55}$ All seven tourism district organisations in the Banská Bystrica region co-operate closely with local municipalities, businesses, non-governmental organisations, active informal groups, volunteers and individuals from local communities in order to avoid one-way and top-down decision-making. As expressed by one of the coordinators: "We cannot imagine some of our activities without our enthusiasts, such as railway or castle fans."

One of the most important parts of the Good Region strategy has been the project to create a network of local and regional producers, artists, farmers etc., and to establish a common platform to give them opportunities to advertise and sell their local products (both tangible and intangible) to local people and visitors. Although these local products are of high quality, the producers often do not have the knowledge, experience and capacity for marketing and distribution. The idea to overcome this challenge has been to introduce Regionálne pulty (the Regional Stands) in six districts of the region that serve as information centres, but mainly as selling points of high quality Regional Products. ${ }^{56}$ In order to get the certification of a Regional Product, these products have to fulfil high quality requirements: they have to represent traditional handmade production and local/ regional origin and uniqueness, and demonstrate high hygiene standards in the case of food products. The label "Regional Product" has been so far given to more than 20 products (Regional product Horehronie, Regional product Podpolanie, Regional product Hont, Regional product Pohronie, Regional product Gemer-Malohont, Regional product Novohrad). ${ }^{57}$

The COVID-19 pandemic (2020-2021) disrupted the activities and enterprises of many local producers in the region including those in the tourism business. The Good Region Development Agency and the Regional Organisation of the Banska Bystrica Tourism did not give up. As all open markets and fairs had to be cancelled, the regional municipality initiated a campaign called "Buy and help". According to Ján Lunter, the regional governor: "The aim

\footnotetext{
53 https://www.zahoramizadolami.sk/rezervuj-si-zazitky/?jump_date=2020-06-01; accessed on 12 June 2020; https://www.facebook.com/327255131213705/videos/993605464387495; accessed on 8 February 2021; https:// www.facebook.com/327255131213705/videos/332143591091982; accessed on 3 February 2021; https://www.facebook.com/zahoramizadolami.sk/; accessed on 2 June 2020.

${ }^{54}$ https://rabbsk.dobrykraj.sk/subory/brozura/BBSK-2roky-Rozvojova-Agentura.pdf; accessed on 6 February 2021.

${ }^{5}$ e.g. OZCEVIK, Ozlem, BEYGO, Cem, AKCAKAYA, Imge (2010). Building capacity through collaborative local action: Case of Matra REGIMA within Zeytinburnu regeneration scheme. In: Journal of Urban Planning and Development, Vol. 136, No. 2, 2010, pp. 169-175.

${ }^{56}$ https://www.zahoramizadolami.sk/regionalne/; accessed on 23 June 2020; https://www.facebook.com/lunter2017/videos/238754819982867; accessed on 11 January 2021.

${ }^{57}$ https://zvonline.sk/regionalne-pulty-ponukaju-vyrobky-lokalnych-producentov-a-remeselnikov/; accessed on 19 May 2020.
} 
of the campaign is to motivate the people to help each other and to support local producers by buying their products." " 58 The campaign's main objective was to enable the online sale of the local producers' products registered on the regional network. Soon after the beginning of the pandemic, the Regional Stands started to offer online sales of more than a hundred products made by more than twenty local producers: honey, wine, jam, syrups, herbal tea and cosmetics, as well as wooden carved products such as crosses or musical instruments.

The Banská Bystrica Good Region Development Agency's overall tourism strategy relies on the concept in which heritage is seen as an important multivalent resource ${ }^{59}$ that can be used for tourism, education, sports, entertainment, skills development, and cultural and creative industries. Similarly, Tunbridge and Ashworth define heritage as a "resource upon which extensive activities or industries have been constructed". ${ }^{0}$ The Good Region strategy strongly supports using heritage as a multiple resource. It also increasingly uses the potential of new technologies in order to unlock the value of cultural heritage in the region and open it to broader tourism audience (by using social media and creating mobile applications, e.g. an app for the Revište castle which comes to life in a playful and entertaining way). If we compare the current situation to the tourism marketing of the region before the establishment of the agency and its regional tourism organisation (2018), we can see that the former marketing was oriented more to attracting tourists to the Low and High Tatra mountains with short visits to mining cities of the region (mainly Banská Bystrica and Banská Štiavnica), monuments, castles and folk architecture reservations. However, this was done without offering unique experiences engaging with local people and culture, learning new skills, doing something unusual—without allowing the tourist to build or co-create his or her own personal experience. As the number of visitors of the Banska Bystrica region has been increasing since the foundation of the agency, ${ }^{61}$ it seems that the new, more targeted and rather innovative communication and marketing strategy works, although it is too early to make any conclusions after less than three years.

\section{Concluding remarks}

Cultural heritage has been one of the most important engines of tourism development in Slovakia in recent decades. It is demonstrated in various tangible and intangible forms (such as visits to historic cities, heritage sites, cathedrals, castles or monuments, known as built or tangible heritage; living cultural heritage that includes people, folklore, customs or foods, defined as intangible heritage; and other forms-industrial heritage; nature-based heritage, personal heritage or dark heritage). This paper's objective was to provide a short overview of key trends in the conceptual development of heritage and heritage tourism studies ${ }^{62}$ and to present a case study from Central Slovakia as an example of the implementation of new tourism destination marketing trends.

Based on recent concepts of heritage and heritage tourism in scholarly literature, we can see the shift from "monuments to people; from objects to functions, and consequently from

\footnotetext{
${ }^{58}$ _https://www.bystricoviny.sk/z-regionu/regionalne-pulty-v-kraji-funguju-aj-pocas-korokrizy-vratane-online-nakupov; accessed on 23 May 2020.

${ }^{59}$ LOULANSKI, Revising the Concept..., pp. 220-221.

${ }^{60}$ TUNBRIDGE, John E., ASHWORD, Gregory J. Dissonant Heritage..., pp. 34-35.

${ }^{61}$ https://kocr.dobrykraj.sk/subory/dokumenty/Sprava-o-cinnosti-a-hospodareni-2018-2019.pdf; accessed on 6 February 2021.

${ }^{62}$ The paper did not aim at covering all contemporary concepts of heritage, mainly because heritage is a territory of different disciplines and domains - cultural, social, economic and environmental.
} 
preservation to sustainable use and development". ${ }^{63}$ The case study of the tourism strategy in the Banská Bystrica Self-Governing Region ("The Good Region") partly reflects these changes. The regional tourism strategy and destination marketing have been built on:

1. the people-local bearers of heritage traditions and their personal stories (this is heritage with a human face);

2. the functions-numerous tourism activities of the Good Region with social and economic objectives (heritage as a human construction cannot be identified without referring to society and its meaning for societal purposes - this refers to the social and economic values of heritage;

3. the sustainability and resilience of heritage as a resource value in several overlapping areas-cultural, economic, social and political. ${ }^{64}$ This can be seen in the continuity of heritage development in numerous local contexts, both in tangible and intangible heritage forms.

Heritage is without any doubt the most powerful source of the tourism development in Slovakia. The country is a place of numerous hidden cultural and natural tourism treasures with a large potential to attract tourists from all over the world. The questions related to the tourism developement are: who, why, where or to which extent. The Good Region Banská Bystrica started to develop a new tourism vision and strategy built on the lesser-known and marginalised districts and destinations of the region with the objective not only to improve and increase cultural and natural experiential tourism, but also to create new job opportunities for local people and even attract young people (sometimes called neorurals) to live in the countryside and develop new activities that could contribute to innovative tourism developments.

In order to achieve these objectives, it is important to create and build new partnerships and bridges between and across all stakeholders involved: state institutions, local and regional municipalities, academia, non-governmental organisations, informal citizen groups and active individuals - but primarily to build and empower local communities. The COVID-19 pandemic revealed new global trends - one of them has been the trend towards de-globalisation. The focus on local developments and stronger local communities based on better communication and collaboration among various actors seems to show the trend for the future. This trend will definitely also have an impact on tourism development. It is too early to make any predictions, but will be exciting to examine further developments.

\section{References}

APOSTOLAKIS, Alexandros (2003). The Convergence Process in Heritage Tourism. In: Annals of Tourism Research, Vol. 40, No. 4, pp. 795-812. ISSN: 0160-7383.

ASHWORTH, Gregory J. (2007). Heritage in Fragments: a Fragmented Instrument for Fragmented Policies. In: MURZYN, Monika, A., PURCHLA, Jacek, eds.: Cultural Heritage in the 21st Century. Opportunities and Challenges. Krakow: International Cultural Centre, pp. 29-41. ISBN 978-83-89273-46-8.

BESSIÈRE, Jacinthe (1998). Local Development and Heritage: Traditional Food and Cuisine as Tourist Attractions in Rural Areas. In: Sociologia Ruralis, Vol. 38, No. 1, pp. 21-34. ISSN 1467-9523.

${ }^{63}$ LOULANSKI, Revising the Concept..., p. 212.

${ }^{64}$ LOULANSKI, Revising the Concept..., pp. 215-220. 
BUI, Huong T., LEE, Timothy J. (2015). Commodification and Politicization of Heritage: Implications for Heritage Tourism and the Imperial Citadel of Thang Long, Hanoi (Vietnam). ASEAS_Austrian Journal of South-East Asian Studies, Vol. 8, No. 2, pp. 187-202. ISSN: 1999-253X.

BURNS, Leah (2004). Anthropology and Tourism: Past Contributions and Future Theoretical Challenges. In: Anthropological Forum, March 2004, pp. 5-22, ISSN 0066-4677.

DODDS, Rachel, BUTLER, Richard (2019). The Phenomena of Overtourism: a Review. In: International Journal of Tourism Cities, Vol. 5, No. 4, pp. 519-528. ISSN: 2056-5607.

EPLER WOOD, Megan, MILSTEIN, Mark, AHAMED-BROADHURST, Kathleen (2019). Destinations at Risk: The Invisible Burden of Tourism. Washington, DC: The Travel Foundation.

GÖSSLING, Stefan, PEETERS, Paul (2015). Assessing tourism's global environmental impact 1900-2050. In: Journal of Sustainable Tourism, Vol. 23, No. 5, pp. 639-59. ISSN: 0966-9582.

GRAHAM, Brian, ASHWORTH, Gregory J., TUNBRIDGE, John E. (2000). A Geography of Heritage. Power, Culture and Economy. London: Routledge. ISBN-13: 978-0340677780.

HARDY, Dennis. 1988. Historical Geography and Heritage Studies. In: Areas, Vol. 20, No. 4., pp. 333-338. ISSN:1475-4762.

HARVEY, David C. (2010). Heritage Pasts and Heritage Presents: temporality, meaning and the scope of heritage studies. In: International Journal of Heritage Studies, Vol. 7, No. 4, pp. 319-338. ISSN: 1352-7258.

LABADI, Sophia (2010). World Heritage, authenticity and post-authenticity. International and national perspectives. In: LABADI, Sophia, LONG, Colin, eds.: Heritage and Globalisation. London and New York: Routledge, pp. 66-84. ISBN 978-0-415-57112-8.

LOULANSKI, Tolina (2006). Revising the Concept for Cultural Heritage: The Argument for a Functional Approach. In: International Journal of Cultural Property, Vol. 13, No. 2, pp. 207233. ISSN: 0940-7391 (Print), 1465-7317 (Online).

LOWENTHAL, David (1998). The Heritage Crusade and the Spoils of History. Cambridge: Camridge University Press. ISBN-13: 978-0521635622.

LUCCHETTI, Veronica Garcia, FONT, Xavier (2013). Community Based Tourism: Critical Success Factors. ICRT Occasional Paper, No. OP27. Australia - Dubai: The International Centre for Responsible Tourism.

LYON, Sarah M., WELLS, E. Christian (2012). Global Tourism: Cultural Heritage and Economic Encounters. Lanham, New York, Toronto, Plymouth, UK: Alta Mira Press. ISBN: 0759120919.

MacCANNELL, Dean (1973). Staged Authenticity: Arrangements of Social Space in Tourist Settings. In: American Journal of Sociology, Vol. 79, No. 3, pp. 589-603. ISSN: 0002-9602.

Marketingová stratégia S ACR na roky 2014-2020 (2013). Bratislava: SACR, pp. 23-24.

NILSSON, Per Åke (2018). Impact of Cultural Heritage on Tourists. The Heritization Process. In: Athens Journal of Tourism, Vol. 5, No. 1, pp. 35-54. e-ISSN: 2241-8148.

OZCEVIK, Ozlem, BEYGO, Cem, AKCAKAYA, Imge (2010). Building capacity through collaborative local action: Case of Matra REGIMA within Zeytinburnu regeneration scheme. In: Journal of Urban Planning and Development, Vol. 136, No. 2, pp. 169-175. ISSN: 07339488. PECHLANER, Harald, INNERHOFEER, Elisa, ERSCHBAMER, Greta (2019). Overtourism. Tourism Management and Solutions. London: Routledge.

ROSENFELD, Raymond. A. (2008). Cultural and Heritage Tourism. In: Municipal Economic Toolkit Project. Michigan: Eastern Michigan University. 
SALAZAR, Noel B. (2010a). From Local to Global (and Back): Towards Glocal Ethnographies of Cultural Tourism. In: GREG Richards and MUNSTERS, Wil, eds.: Cultural Tourism Research Methods. CAB International, pp. 188-198. ISBN 978-1-84593-518-4.

SALAZAR, Noel B. (2010b). The Glocalisation of Heritage through Tourism. Balancing standardisation and differentiation. In: LABADI, Sophia, LONG, Colin, eds.: Heritage and Globalisation. London and New York: Routledge, pp. 130-146. ISBN 978-0-415-57112-8.

SALAZAR, Noel B. (2011). Imagineering cultural heritage for local-to-global audiences. In: HALBERTSMA, Marlite, van STIPRIAAN, Alex, van ULZEN, Patricia, eds.: The Heritage Theatre: Globalisation and Cultural Heritage. Newcastle upon Tyne: Cambridge Scholars Publishing, pp. 49-72. ISBN-13: 978-1443829267.

SALAZAR, Noel B. (2012). Shifting Values and Meanings of Heritage. From Cultural Appropriation to Tourism Interpretation and Back. In: LYON, Sarah and WELLS, E. Christian, eds.: Global Tourism: Cultural Heritage and Economic Encounters. Lanham, New York, Toronto, Plymouth, UK: Alta Mira Press, pp. 21-42. ISBN: 0759120919.

SILVERMAN, Helaine (2015). Heritage and Authenticity. In: WATERTON, Emma, WATSON, Steve, eds.: The Palgrave Handbook of Contemporary Heritage Research. London: Palgrave Macmillan. ISBN: 978-1-349-45123-4.

SMITH, Laurajane (2006). Uses of Heritage. London - New York: Routledge. ISBN: 978-0-41531831-0.

Stratégia rozvoja cestovného ruchu do roku 2020. Adopted by the Government of the Slovak Republic No. 379/ 2013 from 10 July 2013.

TIMOTHY, Dallen J. (2011). Cultural Heritage and Tourism. An Introduction. Bristol - Buffalo Toronto: Channel View Publications. ISBN: 1845412265

TIMOTHY, Dallen J., BOYD, Stephen W. (2003). Heritage Tourism. Harlow, UK: Pearson Education Limited. ISBN 10: 0-582-36970-3.

TIMOTHY, Dallen J., BOYD, Stephen W. (2006). Heritage Tourism in the 21 st Century: Valued Traditions and New Perspectives. In: Journal of Heritage Tourism, Vol. 1, No. 1, pp. 1-16. ISSN: 1743-873X.

TOWNER, John (1996). An Historical Geography of Recreation and Tourism in the Western World: 1540-1940. Chichester: Wiley. ISBN: 0471949906.

TUNBRIDGE, John E., ASHWORD, Gregory J. (1996). Dissonant Heritage: The Management of the Past as a Resource in Conflict. Chichester: J. Wiley. ISBN-13: 978-0471948872.

WINTER, Tim (2010). Heritage Tourism: The Dawn of a New Era? In: LABADI, Sophia, LONG, Colin, eds.: Global Tourism: Cultural Heritage and Economic Encounters. Lanham, New York, Toronto, Plymouth, UK: Alta Mira Press, pp. 117-129. ISBN: 0759120919.

YILMAZ, Emine, YILMAZ, Ekin Enver (2019). Introduction. In: SRIVASTAVA, Surabhi, ed.: Conservation and Promotion of Heritage Tourism. Hershey, PA, USA: IBI Global, pp. xx-xxvi. ISBN: 9781522562832. 